\title{
A
Creating Enable Environment to Harness the Potential of Food Processing Sector in India
}

\section{AMRIT PATEL}

Correspondence to :

AMRIT PATEL

Retired Deputy General

Manager, Bank of Baroda, MUMBAI (M.S.) INDIA

\section{KEY WORDS :}

Food Processing,

Sector, Enable

Environment,

Harness, Potential
ABSTRACT : Farmers' socio-economic welfare in India [more importantly growing number of small and marginal farmers] can get a significant boost if appropriate enabling environment is created to expand food processing sector [FPS] and its growth accelerated to face challenges within India and international markets.Focused attention to harness the latent potential of the FPS can favourably impact upon the much needed crop diversification, cropping intensity, reduction in losses due to wastage of farm produce at various stages, enhance value addition and generate employmentultimately leading to increase in sales in India and exports and higher income to farmers. In the current context of dismal growth rate of agricultureas compared to manufacturing and services sector, the added significance to achieve higher targeted growth rate of FPS lies in ensuring the livelihood of millions of rural households depending upon agriculture [agricultural labourers, tenant farmers, oral lessees, share croppers and those living in drought-prone, desert, tribal and hilly areas], country's food and nutritional security, containing food inflation and reducing pressure on agricultural land. Productivity, production and profitability of farming enterprise and viability of a number of small and marginal farms can be substantially improved through initiating a series of agricultural reforms of which policy and programs relating to FPS, contract farming system, cold storages and supply chain to source a variety of farm produce of better quality in adequate quantity, inter alia, need undivided attention.India ranks first in the world in the production of milk, pulses, ginger, bananas, guavas, papayas and mangoes and second in the production of rice, wheat, vegetable and horticultural products. Food processing technology enables farmers to convert their seasonal and perishable farm produce into several forms of food products that are ready to eat, easy to carry in attractive packets, marketable and having increased shelf-life. The FPS has been growing at a faster rate than agricultural sector. However, according to the Institute of Economic Growth overall level of food processing in India was 6.62 per cent in 2010-11 which needs considerable expansion. This article briefly highlights the significance, current status, Government initiatives, performance of the FPS and suggests the aspects of creating the enabling environment to harness the full potential of the promising FPI.

How to cite this paper : Patel, Amrit (2017). Creating Enable Environment to Harness the Potential of Food Processing Sector in India. Internat. J. Med. Sci., 10(1\&2) : 29-43, DOI : 10.15740/HAS/IJMS/10.1and2/2943.
Paper History :

Received : 25.01.2017; Accepted : 30.09 .2017 